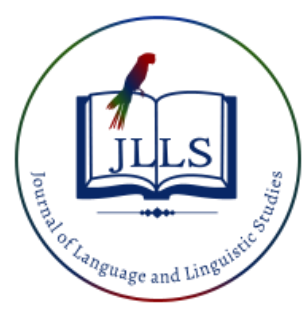

ISSN: 1305-578X

Journal of Language and Linguistic Studies, 17(4), 2022-2045; 2021

\title{
Teaching online during the COVID-19 pandemic: Teachers' perspectives
}

\author{
Yasamiyan Alolaywi a 1 iD \\ ${ }^{a}$ Department of English Language and Translation, College of Science and Arts, Methnab, \\ Qassim University, Saudi Arabia
}

\section{APA Citation}

Alolaywi, Y. (2021). Teaching online during the COVID-19 pandemic: Teachers' perspectives. Journal of Language and Linguistic Studies, 17(4), 2022-2045. Doi: 10.52462/jlls. 146

Submission Date:08/05/2021

Acceptance Date:27/07/2021

\begin{abstract}
The current study aimed to explore EFL instructors' perceptions toward online teaching during the COVID-19 pandemic, with special emphasis on the challenges they faced, and the advantages and disadvantages of this mode of education. The participants in this study were 43 EFL faculty members from the Departments of English at Qassim University in Saudi Arabia. Data for this research were collected by distributing a semi-structured survey designed by the researcher. The results showed that the top advantage of distance teaching was normally protection from the illness. Distance teaching also provided the opportunity to experiment with alternative teaching methods, tools, and assessments. Further, teachers felt exempted from some of the burdens associated with in-person teaching and were allowed to focus on the core role of their profession. Despite these benefits, the participants revealed that e-teaching cannot easily replace traditional education. All in all, the participants reported that e-teaching has advantages for professors, but this is not necessarily the case for students. Implications of these findings are provided, such as training teachers to deal with e-teaching mediums efficiently, keep pace with sudden adjustments, and create monitoring measures to ensure that instructors do not become complacent.
\end{abstract}

Keywords: COVID- 19; e-teaching; teachers' perceptions; teaching online

\section{Introduction}

The outbreak of coronavirus disease in late 2019 (COVID-19) has affected human lives and communities around the world in many ways. Every aspect of society has been affected by this unexpected crisis, including the field of education. The sudden COVID-19 pandemic forced educational institutions to immediately switch from face-to-face education to online education, and thus both instructors and students performed the teaching and learning processes naturally in a virtual environment.

In response to this emergency, distance education or e-learning was imposed on all educational institutions in the Kingdom of Saudi Arabia during the 2020-2021 academic year. The educational process was resumed virtually through the platforms created by online education and communication systems such as Blackboard, Microsoft Teams, and Zoom.

\footnotetext{
${ }^{1}$ Corresponding author.
} 


\section{E-mail address: yalieoy@qu.edu.sa}

It is worth pointing out that this mode of education is not new in the Saudi context. The majority of the Saudi educational institutions have included e-learning as a stand-alone or complementary system in some government facilities. For instance, the Ministry of Higher Education constructed the National Plan for Information Technology to encourage both distance and e-learning education in higher education. In 2006, it created the National e-Learning and Distance Learning Center (NeLC) to offer educators and students with technical support, tools, and the resources to digitalize higher education curricula throughout the country (Alebaikan \& Troudi, 2016).

In recent years, some universities have used learning management systems - such as Blackboard, WebCT, and Tadarus to facilitate learning and teaching online. For example, in 2013, Qassim University launched its Deanship of e-learning and Distance Education, with the main aim of diversifying learning sources. In an official and institutional capacity, the University has given access of Blackboard and Zoom free of charge to students and teachers alike.

Concurrent with this virtual shift, some hypotheses have arisen, and some questions regarding the challenges associated with this new educational system must be answered. In fact, the unexpected rapid and forced shift from face-to-face to remote teaching resulted in major constraints and challenges, but it has also presented some opportunities that must be explored. Challenges, according to Hazaea et al., (2021) have been associated with inefficient infrastructure of online teaching, teacher inexperience and limited competence in digital instruction, the learning gap, complex home environments, institution and stakeholder adaptation to the environment created by the COVID-19 pandemic, training strategies, and innovations.

This period of change required an evidence-based perspective on what would and would not work and, most importantly, an understanding of the features, outcomes, processes, and implications of online teaching. Thus, this paper reviewed the literature available on the most important advantages and disadvantages of this mode of teaching, from the perspective of English department faculty members at Qassim University.

\subsection{Research Questions}

The present study aims to answer the following research questions :

1 .What are Saudi EFL university instructors' perceptions toward online education during the COVID-19 pandemic?

2 .What are the advantages of online teaching from the instructors' perspectives?

3. What are the disadvantages of online teaching from the instructors' perspectives?

\subsection{Significance of the Study}

The significance of this study can be summarized as follows:

1. The findings of this study will contribute to identifying the advantages and disadvantages of distance education from the perspective of university professors.

2. Exploring the obstacles and problems of distance education that professors faced will help identify solutions to avoid them in the future and improve performance.

3. The current study will support previous research in this field, either negatively or affirmingly, which will ultimately lead to a refutation or reinforcement of results.

4. Assessing the effectiveness of e-learning will determine whether it is feasible to include this means of education as a complementary learning method in the future. 
5. Performance appraisal from the perspective of participants in the field of education will be of benefit to relevant policymakers and decision-makers.

\section{Limitations of the Study}

There are two limitations in this study: firstly, the sample of the study is relatively small, which could limit the generalization of the findings to a large population. In addition, the sample was selected from one educational region and was confined to one university.

Secondly, there is only one data collection tool used in this research; which is the survey, while diversifying research tools and the inclusion of other methods such as interviews, will certainly provide more in-depth insight and understanding of the research hypotheses .

\section{Literature Review}

Many recent studies which have been conducted on the transition to online teaching during the Covid-19 pandemic have yielded some important findings (Al-Ahdal \& Alqasham, 2020; Abduh, 2021; Almansour et al., 2020; Alves et al., 2021; Bailey and Lee, 2020; Hazaea et al., 2021; Kitishat et al., 2020; Shamsan et al., 20121). These studies were mainly limited to research conducted in 2020 and 2021, which are the years following the outbreak of the crisis (Coronavirus disease). The review below has focused on two main axes: the most important challenges and gains of e-learning.

To map the benefits and challenges of implementing an online EFL course among teachers, Bailey and Lee (2020) surveyed some EFL university instructors teaching communication courses in a South Korean university. Findings revealed that instructors with online teaching experience perceived less obstacles and used a wide array of communication channels and activities when teaching. Kitishat et al. (2020) investigated the effect of COVID-19 crisis on English language teaching. They explored the impact of transferring to new approaches influenced the teaching process. The propinquity of teaching environments and timing systems allow students to concentrate and focus on their answers in light of time limits. The study concluded that online teaching can be greatly beneficial by offering a chance for effective teaching. This would also help in enhancing students' scholarly accomplishments. On the feasibility of digital content in the learning process during the pandemic, Fansury et al. (2020) pointed out that the use of digital content in teaching English can increase students' motivation and interest and is very helpful for students in understanding materials during the pandemic. Upon using digital content, the learning process becomes easy because it can be directly integrated into various applications, such as WhatsApp groups, Zoom, Google Meet, etc.

Many studies have found a combination of disadvantages and advantages associated with elearning. For example, Khatoony and Nezhadmehr (2020) studied the challenges that EFL Iranian teachers encounter while applying online teaching during Covid-19 pandemic. The findings indicated that Iranian EFL teachers faced many challenges. Still, they could use the applications and platforms competently. The challenges they faced include the lack of suitable teaching materials, learners' less attention and motivation toward online classes, and the shortage in funding and support for educational institutions. On the contrary, the results showed that the majority of teachers constructed positive beliefs about the use of technology in Iran. They confirmed that technologies can be beneficial to minimize the distance between learners and teachers. Similarly, Yi and Jang (2020) envisioned some possibilities related to the practices of remote teaching in two school EFL teachers in South Korea. They concluded that the shift from face-to-face to remote teaching and learning has challenged all teachers, students, parents, and administrators. Nevertheless, the result revealed that both the crises and distance teaching have forced teachers to become innovative and cooperative in their instruction. Moreover, Tamah et al. (2020) explored language teachers' online engagements during the COVID-19 
pandemic in Indonesia. Although the teachers in this study were struggling to enhance the quality of online learning engagement, the authors found that most of the participating teachers, within a short period, have enhanced their technological knowledge regardless of their prior exposure to technology.

Lestiyanawati (2020) explored and described the applied strategies and problems that Indonesian teachers faced in conducting e-learning during this COVID-19 outbreak. The findings revealed that teachers reported: their disability in accessing technologies and school facilities in supporting elearning, their difficulties in explaining the material, students' limitations in accessing the internet, students' economically disadvantaged family backgrounds, and parents' support systems. Nevertheless, the teachers also expressed that the e-learning system greatly relieved their responsibility in conducting teaching and learning processes during this COVID-19 outbreak.

Likewise, Sepulveda-Escobar and Morrison (2020) carried out a case study with twenty-seven Chilean EFL teacher candidates to explore the challenges and chances of the virtual teaching experience. The finding revealed that the less interactions between teacher and learners as well as the changing of education settings were among factors that strongly affected the learners' own learning processes. In spite of the devastative challenges presented, both students and teachers proposed that this unique experience would positively contribute to sharpen their teachers' experience and their future careers.

Likely, Abduh (2021) explored Saudi EFL teachers' perceptions of e-learning and the challenges that they faced while assessing students online. The results showed that the EFL teachers had a moderate attitude toward the assessment. In addition, most of the questionnaire items belonging to the teachers' perceptions of techniques and methods were positive. In contrast, most statements related to the teachers' perceptions of challenges they faced while assessing students online scored (high) very high. In Pakistan, Mukhtar et al. (2020) examined both the perceptions of teachers and students of the advantages and limitations of remote learning. They found that the advantages included comfort and accessibility, whereas the limitations involved inefficiency and difficulty in maintaining academic integrity. Finally, Alves et al. (2021) studied the factors behind the professional well-being of teachers amid the COVID-19 crises in the Portuguese context. The teachers were satisfied with the education system before the pandemic. The pandemic has reduced the perception of well-being in the face of the profession, creating some concern among teachers about their career length of service, well-being, perceptions of teaching difficulties, and future perspectives proved to be predictors of professional well-being in times of the pandemic.

Other reviews focused on the obstacles associated with e-learning. For instance, Putri et al. (2020) investigated the restrictions of the online teaching and learning process at home as a result of the COVID-19 pandemic. The respondents included 15 teachers and parents of two primary schools in Indonesia. Teachers showed some challenges and constraints, including selecting the appropriate methods of teaching applicable in a regular traditional face-to-face class, fewer coverage of syllabus content, the lack experience in using technology which limit the potentiality of online learning, the shortage of e-resources needed to develop e-contents. In the same vein, and still in Indonesian context, Atmojo and Nugroho (2020) studied the Indonesian EFL teachers' reflections on their practices of online EFL learning programs and the constraints they faced in an individual follow-up interview. Findings revealed that many problems appeared from the students, teachers, and parents, along with many other valid reasons. Therefore, online learning was found inefficient, given that it required both planning and preparation.

Al-Khresheh (2021) investigated to what extent the pandemic has influenced and informed Jordanian EFL teachers' beliefs on EFL teaching. The teachers explained how undertaking pedagogical activities had been drastically restricted and complicated due to the pandemic limiting 
education to online platforms. The most important aspect for maintaining EFL teaching was to provide students with a constructive learning environment outside of the school context, taking the fact that traditional teaching methods are unattainable due to concerns for health and safety. This was then developed into the third point, in which teachers emphasized the special skill set required to efficiently conduct lessons for EFL students, which placed an increased strain on educators. The skillset is categorized by four inclusive teaching areas: presuming, planning, preparing, and performing (hence, 4 P's). Kundu and Bej (2020) conducted an exploratory study to find out what barriers and successes that teachers faced while applying online teaching-learning. The participants included 141 teachers from all over the globe. Findings highlighted that both teachers and the education systems were not fully ready for this shift. The teachers encountered various hurdles such as the lack of student and parents' engagement, the need for training, the difficult to access to digital equipment, unclear monitoring mechanisms, and other systematic obstacles.

Nashir and Laili (2021) carried out a study on the perception of English teachers towards the shift from face-to-face teaching into online teaching during the outbreak of COVID-19 with 50 English teachers from Banyuwangi. The results of the study indicated that teachers' perceptions of virtual teaching have not been precisely evaluated. Only approximately $35 \%$ of learners were active and highly serious in emerging in out virtual learning and submitting their assignments on time because teachers could not suitably monitor students' learning activities. Approximately $68 \%$ of the teachers felt that their workload was heavier compared with that in face-to-face learning because they needed more time to operate suitable virtual learning media, apart from learning to boost students' motivations and desires in English lessons. Finally, Astuti and Solikhah (2021) explored teachers' perceptions of teaching English using the online system and described how teachers prepare to teach objectives, teaching materials, teaching methods, and evaluation processes during the COVID-19 outbreak. Findings showed that teaching English virtually is apprehended to be challenging. The limited availability of support systems and quotas of the internet was the basic obstacle. Some of the applicable methods of teaching or online teaching were mainly Google Classroom and Google Meet because learners only had Android mobile to access the online lessons through. The process of evaluation was fully dependent on Google Forms; paper-based evaluations were taken, with the students expected and required to submit their work online.

In conclusion, Nambiar (2020) identified some of the important areas that satisfy both teacher and students with online classes: timely and quality interplay between students and professors, availability of technology, structured modules for online class, and alterations to normalize the execution of practical classes.

\section{Method}

\subsection{Population and Participants}

The population for this research consisted of faculty members at Qassim University who taught English to tertiary-level students at various colleges of arts in the region. They included 44 faculty members comprising 50\% males $(n=22)$ and 50\% females $(n=22)$. These teachers are affiliated with Qassim University and belong to its various colleges, namely the College of Science and Arts in AlMithnb, the College of Science and Arts in Unayzah, the College of Arabic Language and Social Studies in Buraidah, and the College of Humanities in Buraidah. As for their scientific degrees, only one participant (2.3\%) holds a post-doctoral degree, twenty-one (47.7\%) are $\mathrm{PhD}$ holders, 13 (29.5\%) are master's degree holders, and nine (20.5\%) hold a bachelor's degree. The average years of experience for these professors is approximately ten years. Regarding their positions, two (4.5\%) are associate professors, a vast majority $(\mathrm{n}=17)$ are assistant professors $(38.6 \%)$, sixteen $(36.4 \%)$ are 
lecturers, eight $(18.2 \%)$ are teaching assistants, and one $(2.3 \%)$ is a language teacher. Figure 1, below illustrates the educational platforms that the professors prefer to use:

Which educational platform are you currently using?

44 responses

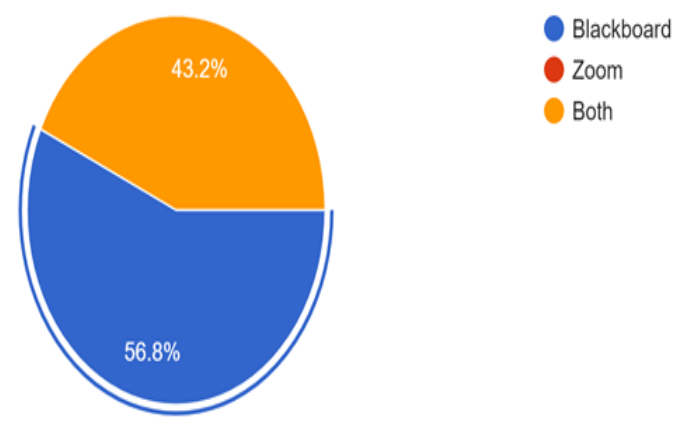

Figure 1. Educational Platforms Used During the Pandemic

The instructors were questioned about their preference for one medium over the other, particularly Blackboard. As illustrated in the graph above, they stated that the main reason for their preference is that in addition to the features and tools that Blackboard has that facilitate and enrich the educational process, it is the official platform approved for electronic teaching by the university. Notably, this platform is linked to the database of teachers and students alike on the official system of the university. The professors who prefer the Zoom platform find it easier to load than Blackboard, especially in conditions of slow internet and weak network signals.

\subsection{Research Design and Data Collection}

The data for this research were collected during the second semester of the academic year 20202021. An online survey devised by the researcher was used as a data-gathering tool. The survey comprised 28 closed-ended and open-ended questions inquiring about demographic, factual, and attitudinal information of the participants (Appendix A). It was designed in accordance with the five point Likert-scale survey format. This study employed a survey design. Data were analyzed utilizing quantitative and qualitative approaches corresponding to the question type. Frequency counts were generated to estimate the mean of the responses to each question .

\subsection{Data Analysis and Results}

Item 2: Technical Problems Experienced by the Teachers

Reviewing the teachers' responses to whether they frequently encounter technical problems while teaching online (Figure 2), the majority of them, $43.2 \%$, disagreed, $22.7 \%$ strongly disagreed, $9.1 \%$ were neutral, $22.7 \%$ agreed, and $2.3 \%$ strongly agreed. 


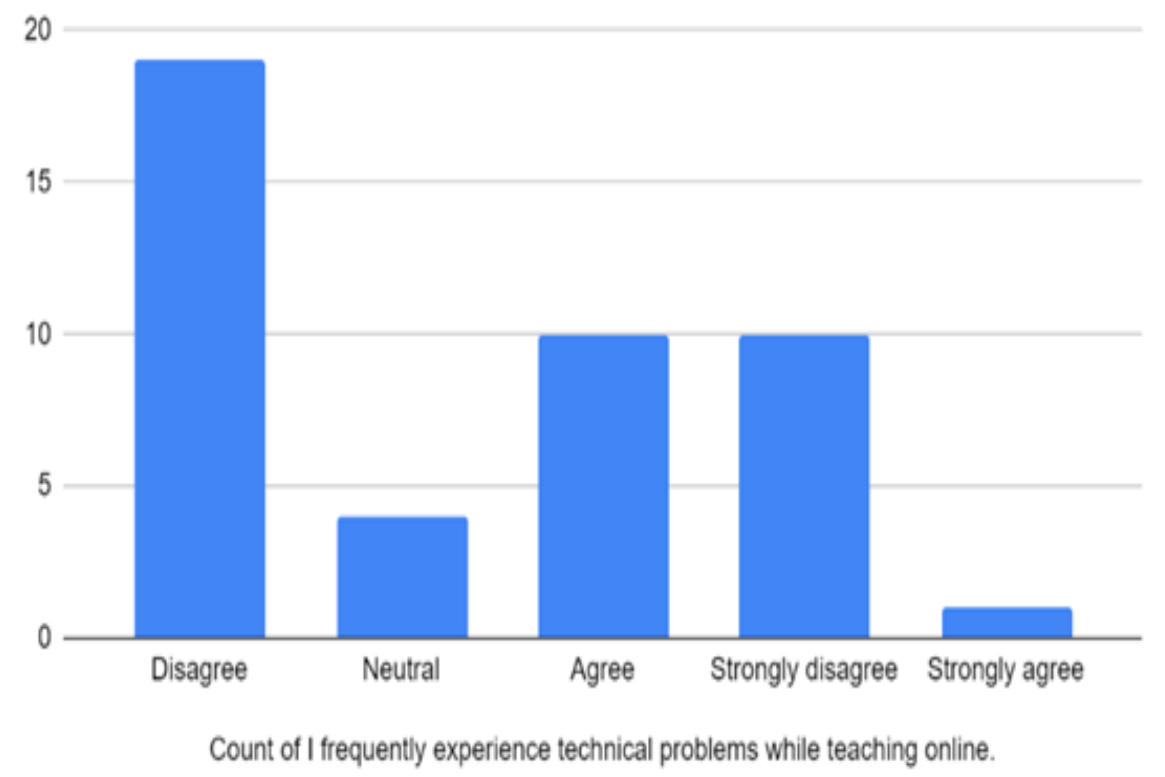

Figure 2. Technical Problems Experienced by the Teachers

Figure 3 shows that nearly about half of the participants, $45.5 \%$, agreed that online teaching platforms offer innovative teaching methods. Contrarily, 34.1\% disagreed, $9.1 \%$ strongly disagreed, $9.1 \%$ were neutral, and $2.3 \%$ strongly agreed.

Item 3: Do teaching platforms offer innovative methods of teaching?

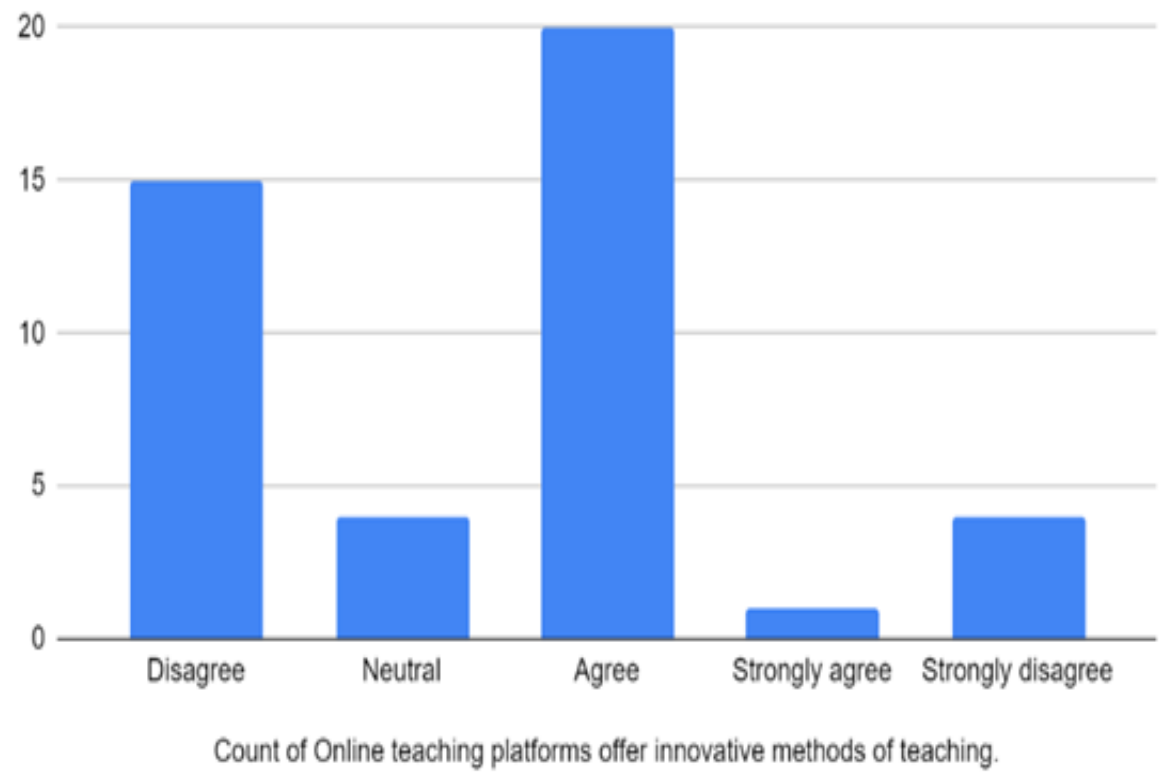

Figure 3. Whether Teaching Platforms Offer Innovative Methods of Teaching

When asked if they think that their students could fully understand lectures through the online medium (Figure 4), teachers' responses were mostly in favor of students' inability to understand online lectures adequately as $40.9 \%$ disagreed, $34.1 \%$ were neutral, and only $25 \%$ agreed. 


\section{Item 4: Students' Comprehension of Online Lectures}

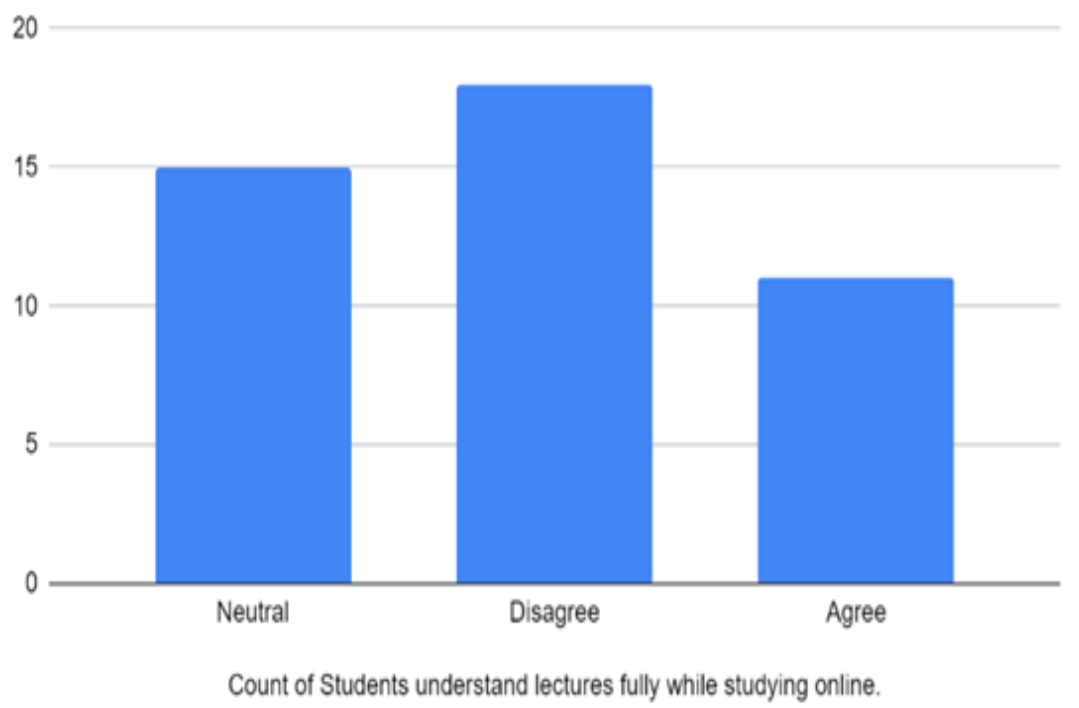

Figure 4. Students' Comprehension of Online Lectures

Figure 5 displays that $59.1 \%$ of the participants agreed that their students struggled with online learning; $9.1 \%$ strongly agreed, $15.9 \%$ were neutral, $13.6 \%$ disagreed, and $2.3 \%$ strongly disagreed.

\section{Item 5: Students' Struggle with Online Learning}

$$
30
$$

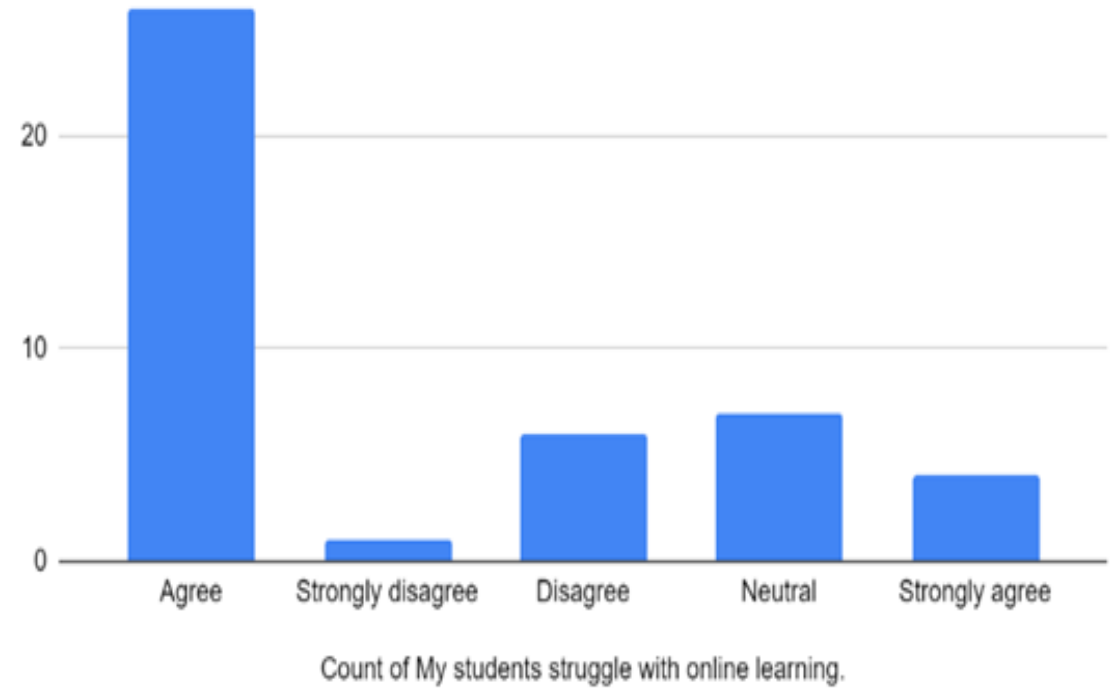

Figure 5. Students' Struggle with Online Learning

Moreover, when questioned whether the online learning environment was not an interactive teaching environment (Figure 6), 45.5\% of the participants agreed, $4.5 \%$ strongly agreed, $27.3 \%$ disagreed, and $22.7 \%$ were neutral. 
Item 6: Is the Online Environment an Interactive Environment?

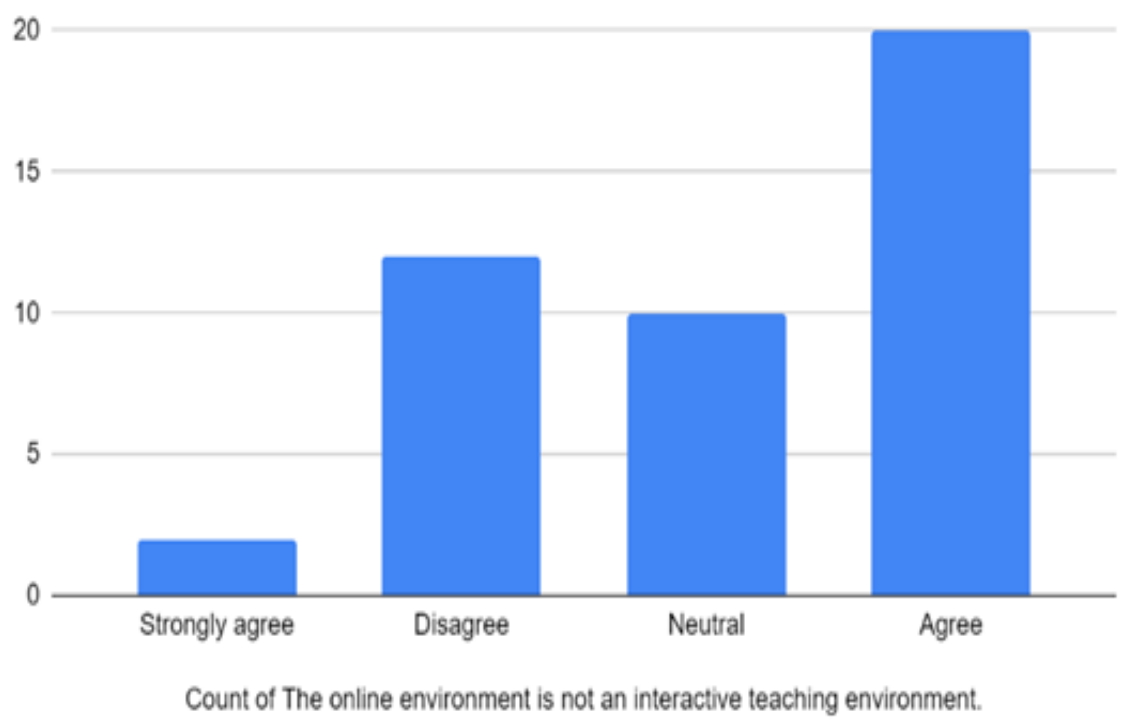

Figure 6. Whether the Online Environment is an Interactive One

When the teachers were asked if the teaching techniques are limited within virtual classrooms (Figure 7), 59.1\% agreed, 20.5\% were neutral, and 20.5\% disagreed.

\section{Item 7: Teaching Techniques within Virtual Classrooms}

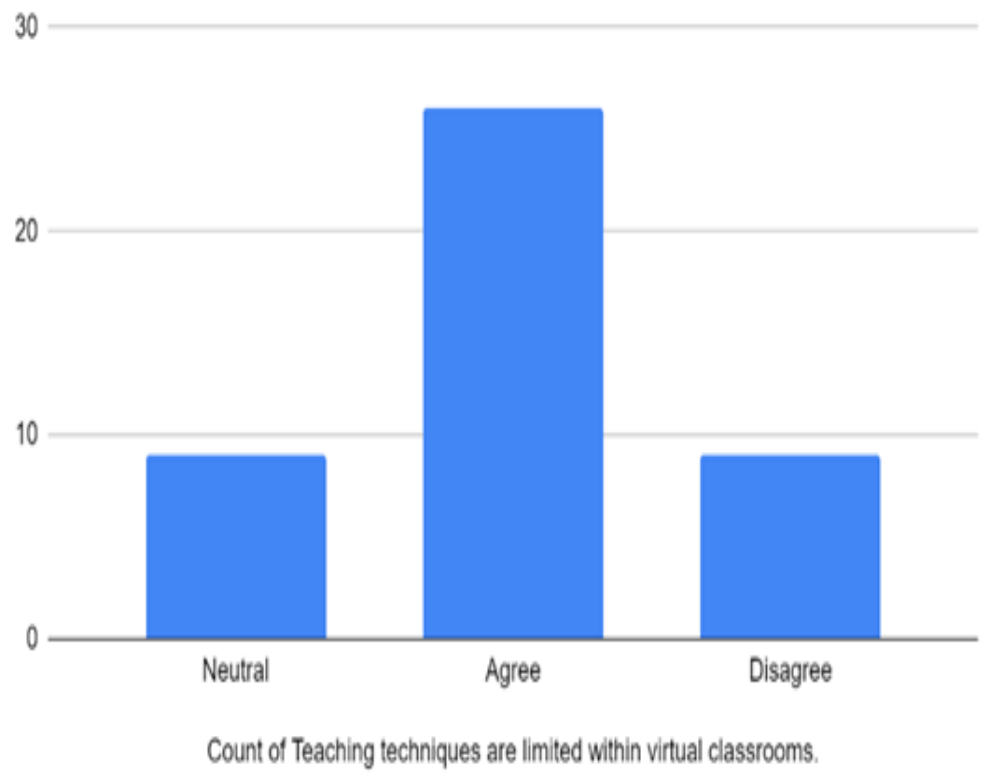

Figure 7. Teaching Techniques Within Virtual Classrooms

However, when asked if online media offer additional tools useful for in-class discussions (e.g., live chats and audible answers) (Figure 8), most participants, 56.8\%, agreed, 25\% strongly agreed, $9.1 \%$ disagreed, and $9.1 \%$ were neutral. 


\section{Item 8: Additional Tools for Online Discussions}

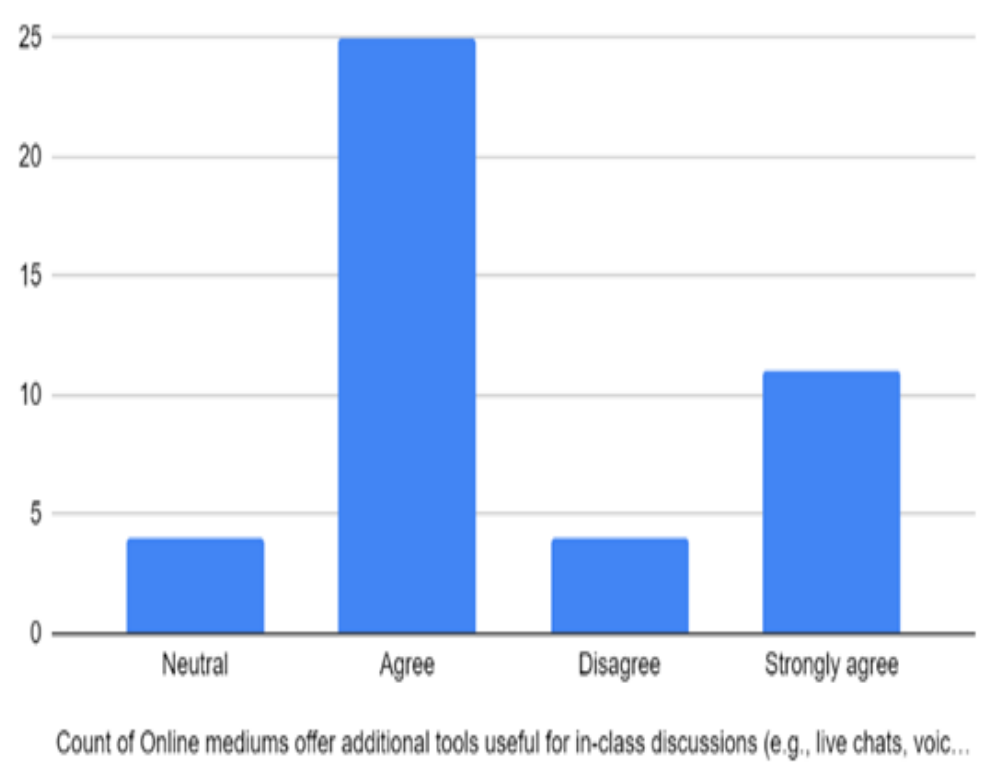

Figure 8. Additional Tools for Online Discussions

Responding to the question about students' interaction levels with their instructors through online teaching channels (Figure 9), 36.4\% agreed with the teachers/participants, 9.1\% strongly agreed, $34.1 \%$ disagreed, and $20.5 \%$ were neutral.

\section{Item 9: Students' Interactions Via Online Mediums}

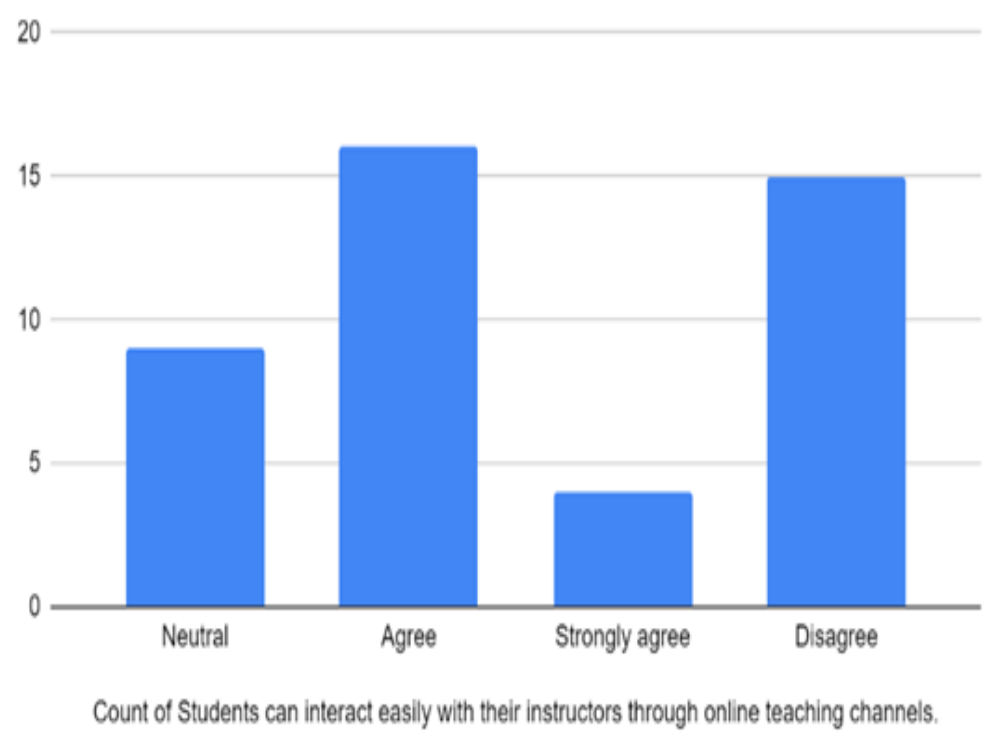

Figure 9. Students' Interactions Via Online Mediums

Figure 10 shows that $38.6 \%$ of the teachers agreed that they could easily assess their students and track their progress while teaching online, $2.3 \%$ strongly agreed, $29.5 \%$ were neutral, $25 \%$ disagreed, and $2.5 \%$ strongly disagreed. 
Item 10: Assessment of Students Via Online Channels

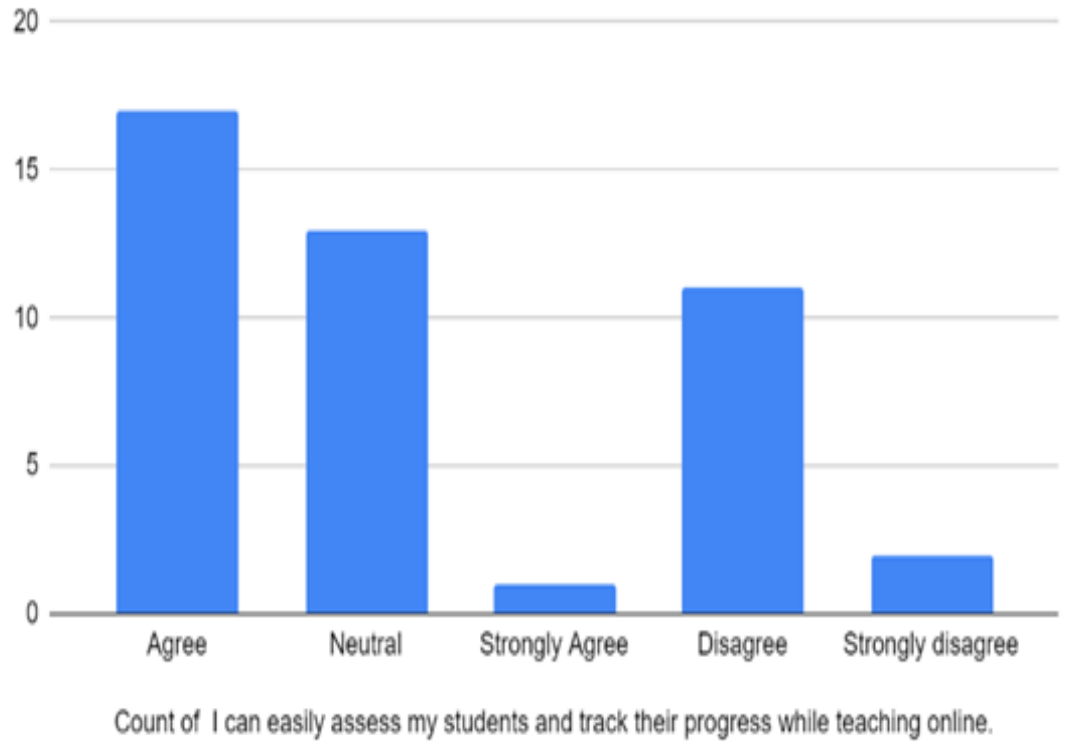

Figure 10. Assessment of Students Via Online Channels

When questioned if online teaching platforms offer innovative assessment methods (Figure 11), the majority of the participants, $63.6 \%$, agreed, $9.1 \%$ strongly agreed, $13.6 \%$ were neutral, $4.5 \%$ strongly disagreed, and $9.1 \%$ disagreed.

\section{Item 11: Online Teaching and Assessment}

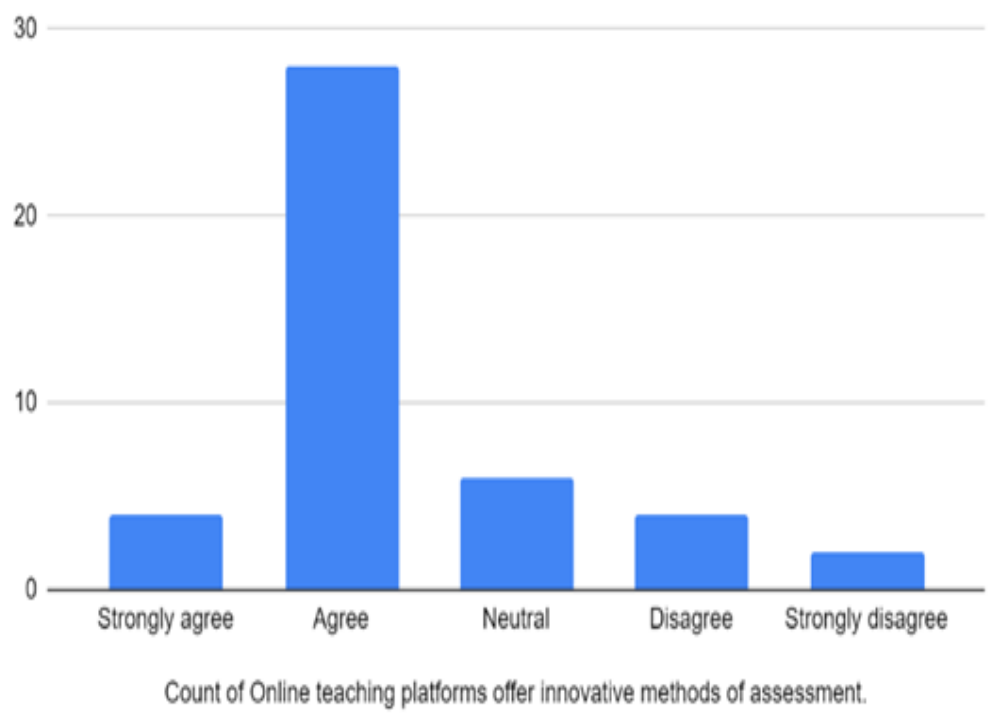

Figure 11. Online Teaching and Assessment

Regarding whether they enjoyed the online teaching experience (Figure 12), 59.1\% agreed, 4.5\% strongly agreed, $29.5 \%$ were neutral, and $6.8 \%$ disagreed. 


\section{Item 12: General Assessment of the Online Teaching Experience}

30

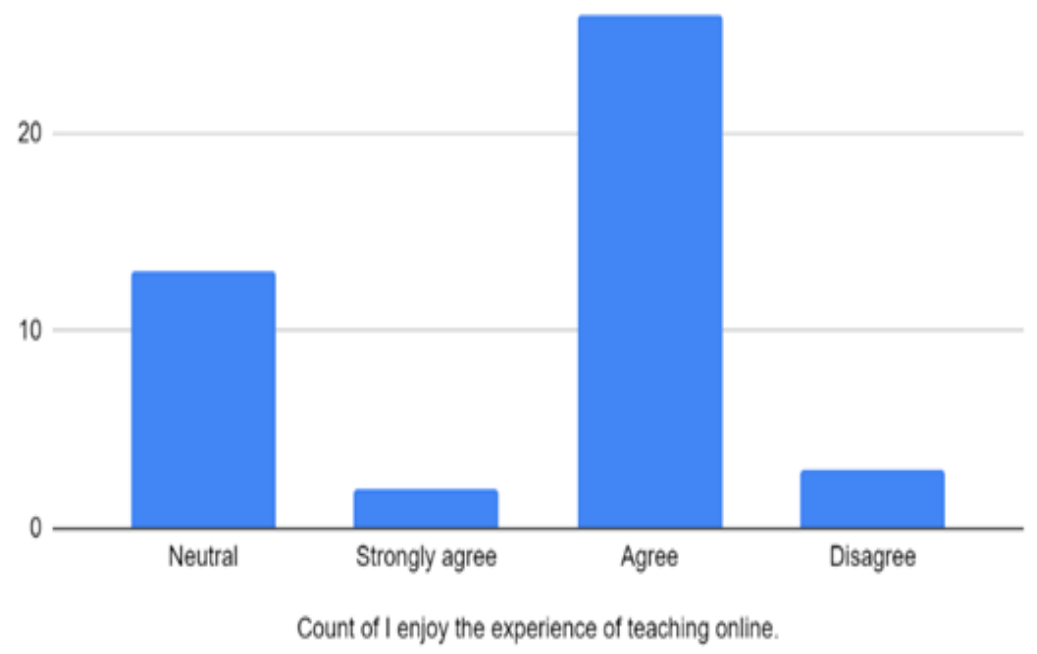

Figure 12. General Assessment of the Online Teaching Experience

Additionally, when asked if they preferred online teaching to traditional in-class teaching (Figure 13), $52.3 \%$ of the teachers disagreed, $9.1 \%$ strongly disagreed, $18.2 \%$ were neutral, $18.2 \%$ agreed, and $2.3 \%$ strongly agreed.

Item 13: Online Teaching or Traditional in-class Teaching?

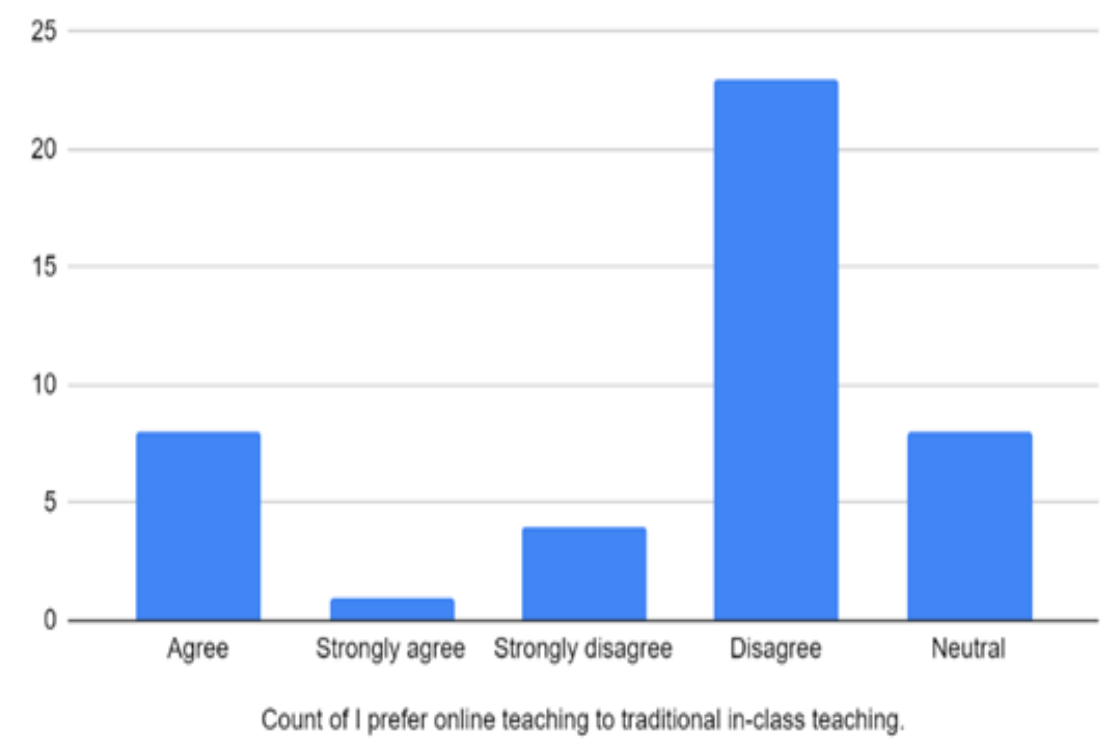

Figure 13. Preference of Online Teaching to Traditional Teaching

Figure 14 displays the teachers' responses to whether educational platforms offer multimediateaching tools absent in traditional classrooms, such as audio and visual aids. Most participants, $52.3 \%$, agreed, $25 \%$ strongly agreed, $13.6 \%$ were neutral, and $9.1 \%$ disagreed. 
Item 14: Multimedia Tools in the Online Classroom

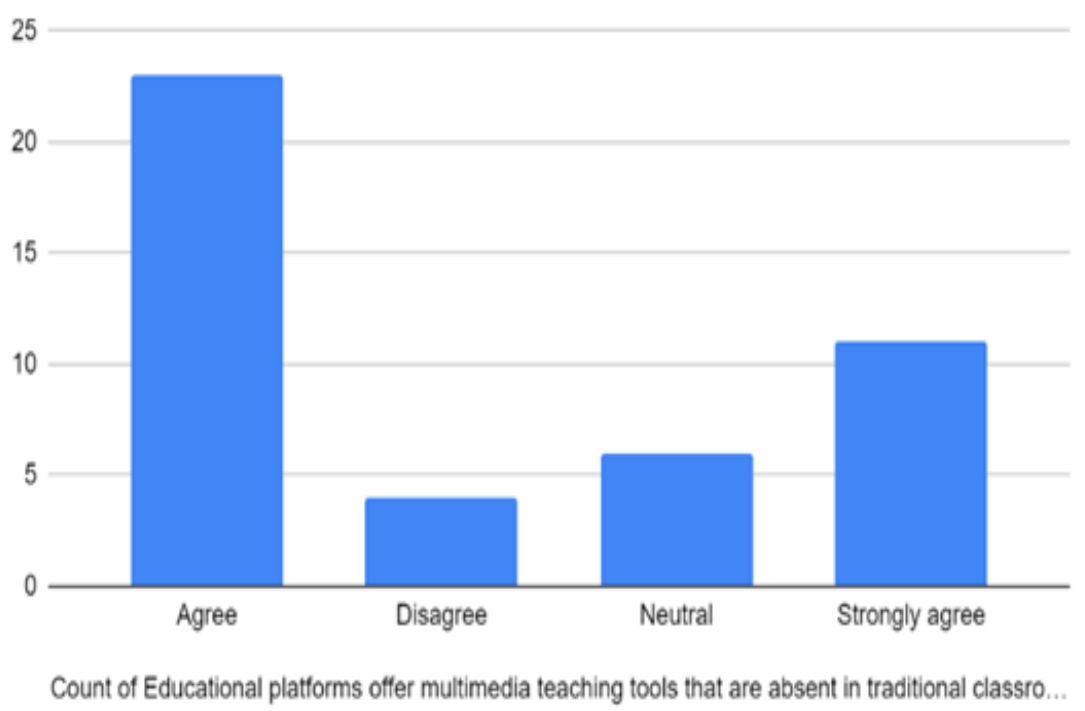

Figure 14. Multimedia Tools Used in the Online Classroom

Figure 15 shows that $61.4 \%$ of the teachers took advantage of online educational platform tools; $22.7 \%$ were neutral, and $15.9 \%$ did not use it.

Item 15: Extent of Utilization of Online Teaching Tools

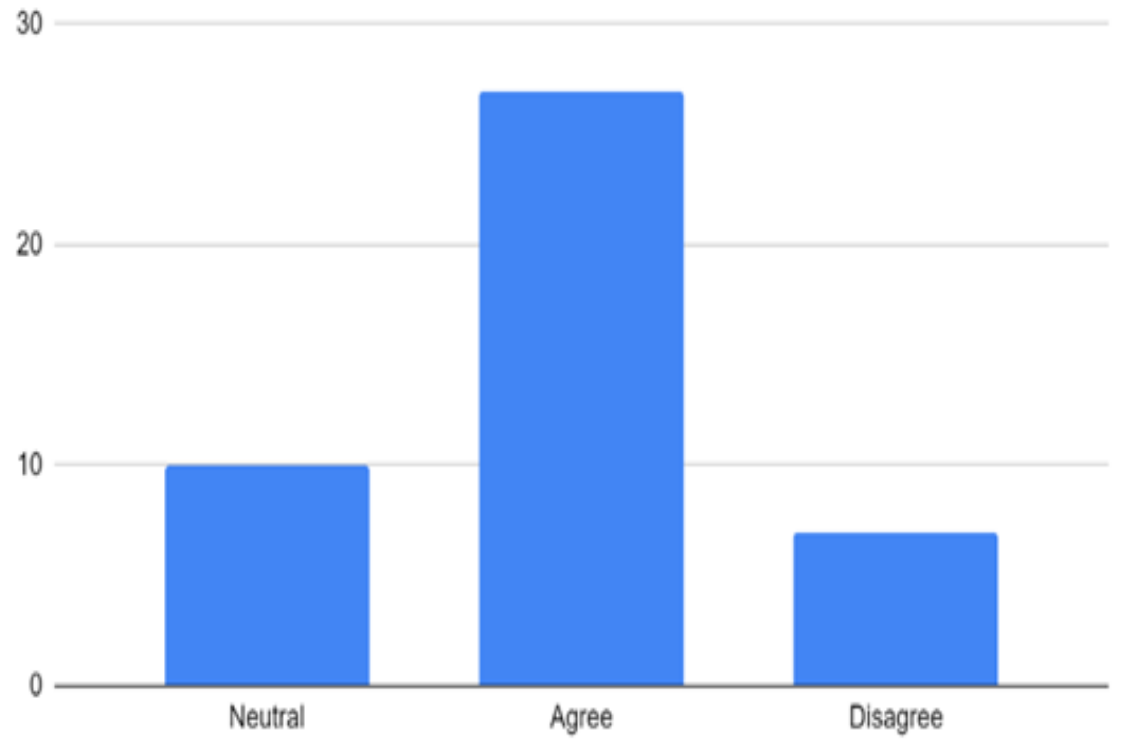

Count of I take advantage of online educational platform tools.

Figure 15. Utilization of Online Teaching Tools

However, when questioned if they think that online teaching can easily replace traditional in-class teaching (Figure 16), the majority of the participants, $65.9 \%$, disagreed, $11.4 \%$ strongly disagreed, $18.2 \%$ were neutral, and $4.5 \%$ agreed. 
Item 16: Possibility of Substituting Traditional Teaching with Online Teaching

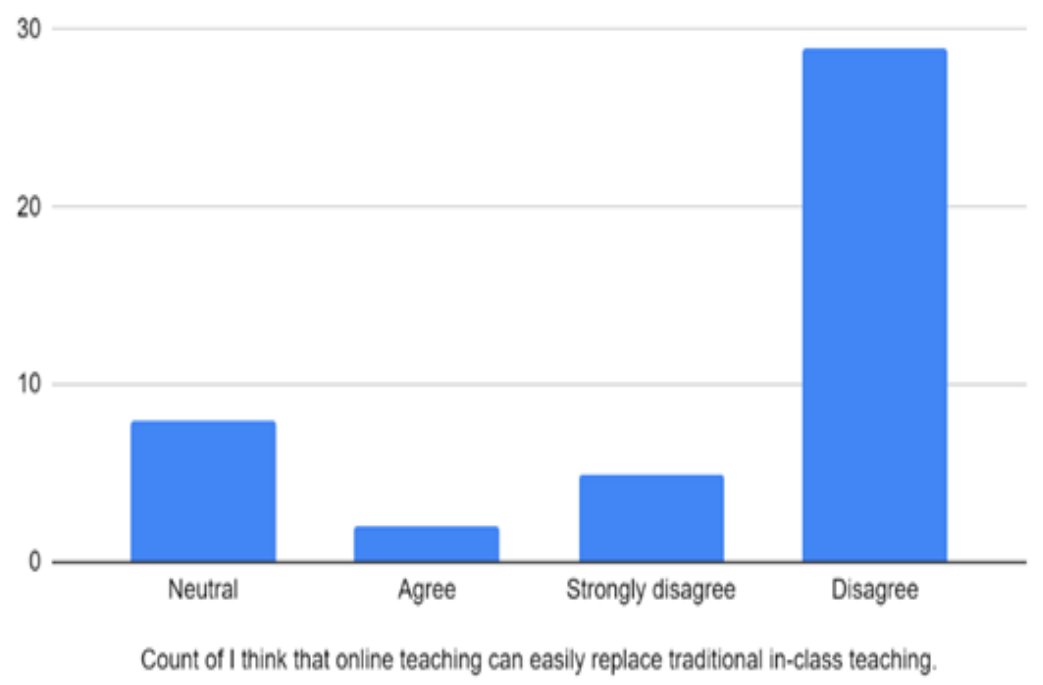

Figure 16. Whether Online Teaching Replaces Traditional Teaching

Reviewing the teachers' responses related to whether online studying negatively impacts students' performance (Figure 17), most of them, 63.6\%, disagreed, 9.1\% strongly disagreed, $15.9 \%$ were neutral, and $11.4 \%$ agreed.

Item 17: Online Education and Students' Performances

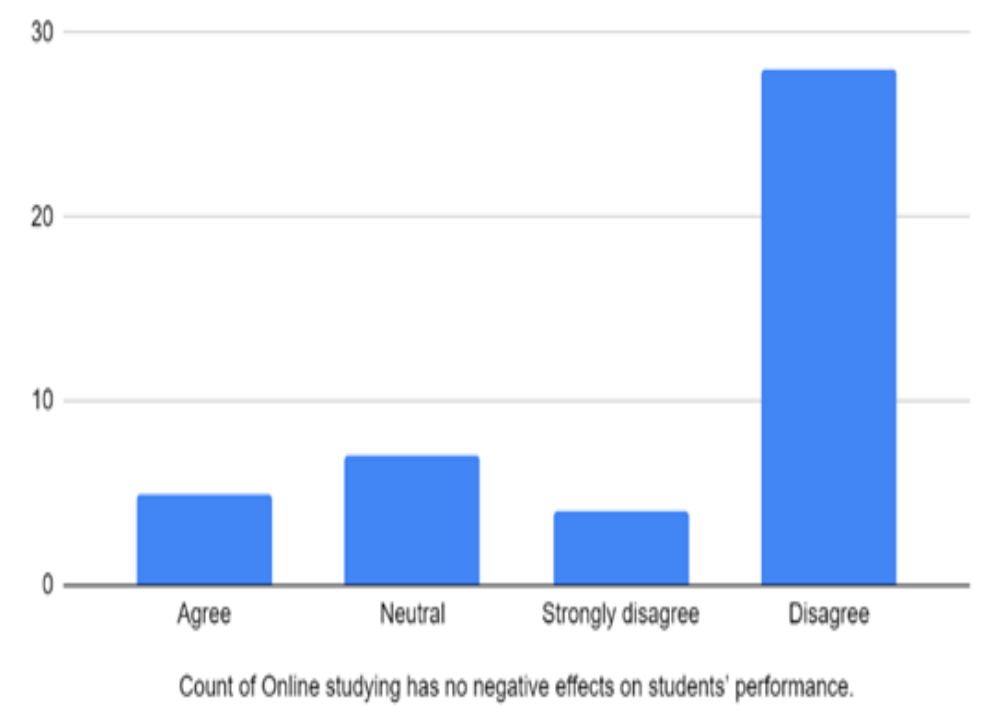

Figure 17. Online Education and Students' Performances

In response to the statement: "I see no change in students' achievement levels as a result of online learning" (Figure 18), 56.8\% of the participants disagreed, $13.6 \%$ strongly disagreed, $20.5 \%$ were neutral, and $9.1 \%$ agreed. 
Item 18: Changes in the Students' Achievements as a Result of Online Learning

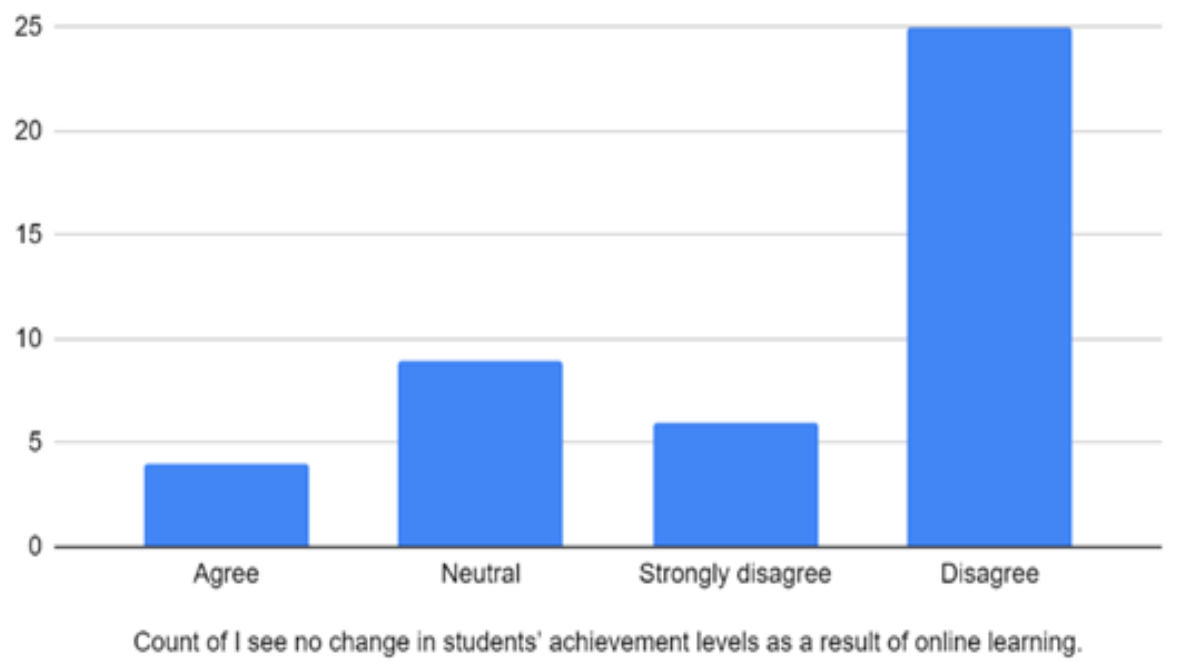

Figure 18. Changes in the Students' Achievements as a Result of Online Learning

However, when surveyed about whether they found online teaching to be boring (Figure 19), $36.4 \%$ disagreed, $2.3 \%$ strongly disagreed, $22.7 \%$ were neutral, $27.3 \%$ agreed, and $11.4 \%$ strongly agreed.

Item 19: Is Teaching Online Boring?

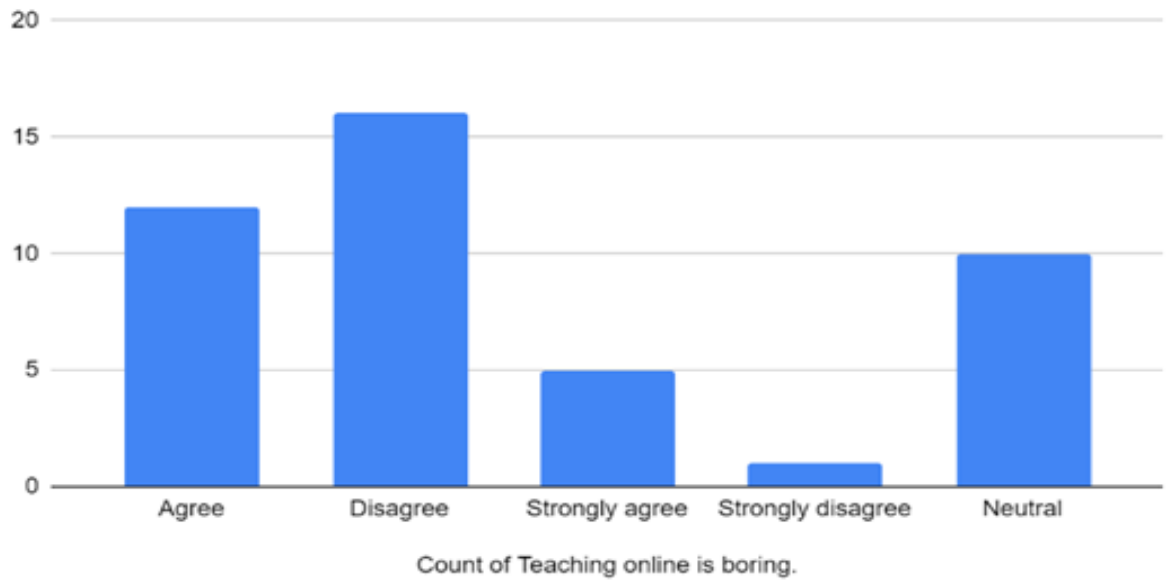

Figure 19. Online Teaching

The teachers reflected that the main advantages of online teaching included: accessibility, timesaving, diverse tools, new methods of teaching and assessment, among others. The following are some of the teachers' responses to this item:

- Time-saving, resource accessibility, and teaching documentation.

- Use of interactive tools, the ease of material sharing, the efficiency of lecture delivery.

- The only advantage is that students do not commute.

- Can accept a wider audience.

- New methods of teaching can be attempted. 
- Good experience with technology and saves time.

- Students need not come from far-off distances; teachers are never rushed when returning to their residences. The entire lecture time of the lecture is utilized.

- Time-saving.

- Practicing language while protecting oneself from the virus.

- Multiple teaching options.

- Interesting material/content.

In contrast, the disadvantages of online teaching from the teachers' points of view can be summarized in the following replies:

- Increased preparation time and technical glitches.

- Network problems: cannot see students' facial expressions; the system requires proper training.

- You cannot achieve authentic teaching.

- Technical failures.

- There is no proper interaction between teachers and students.

- Little interaction: teaching techniques are limited.

- Students do not fully pay attention because the teacher is behind the screen. Teachers fail to fully meet the individual needs of students.

- Some students have a weak internet connection, which may affect their attendance.

- Unable to see students' impressions.

- Low assessment accuracy; low student performance.

- Lack of response.

\section{Discussion}

Through a survey of the results of the study and an analysis of teachers' opinions on e-learning, a consensus was discovered that online education has both positive and negative effects. One of the most prominent advantages of virtual education is that it allows teachers to experiment with a new educational method and take advantage of the tools it provides and the techniques it enables, which leads to more effective education. This result is consistent with Kitishat et al.'s (2020). They found that online teaching offers great benefits by providing a chance for effective teaching and therefore leading to better learning outcomes. It is worth noting that the obstacles faced by the instructors' participating in the study while using this technology are very limited compared to the obstacles faced by students. This is also consistent with the findings of the study conducted by Lee (2020), which concluded that instructors with virtual teaching experience faced minor challenges and used various channels of communication and activities when doing so. In fact, most of the participants in the current study agreed that students, rather than teachers, face technical problems at this stage.

In contrast to some previous studies, such as the one carried out by Putri et al. (2020), the current study concludes that teachers deal well with technology and have sufficient skills to conduct online lessons. On the other hand, the current study results are confirmed with the results of Al-Khresheh's (2021) study which found that the virtual educational environment is not ideal due to the absence of direct, effective communication between the teacher and the student, which affects the quality of the educational process. It is also consistent with the findings of Bej (2020), who stressed that a lack of 
real student engagement and a lack of access to digital equipment represent the main challenges of elearning .

The participants in the current study pointed out that one of the most prominent advantages of elearning is that it exempts them from some routine and secondary tasks, which may sometimes cause a lack of focus on the main duty of teaching. This is consistent with Lestiyanawati's study (2020) but contrary to the conclusion of a study by Nashir and Laili (2021), who indicated that their teacher participants felt that their workload was heavier with e-learning than traditional learning as they needed more time to present suitable virtual learning media and package enjoyable lessons to boost students' motivation to follow English lessons.

As for students' interactions through electronic channels, the current study indicated that interaction was not as required. This has already been proven by the results of previous studies, such as the one by Nashir and Laili (2021), who found that only about 35\% of students were active in following the course and submitting assignments on time because of the shortage of resilience, and teachers' access to mounter students' learning activities, and another by Khatoony and Nezhadmehr (2020), who explained learners' lack of attention and motivation in virtual classes.

Most of the participants of the current study agreed that online teaching platforms offer innovative methods of teaching and assessment. This bears some resemblance to the findings of Tamah et al. (2020) and Yi and Jang (2020), who reported that the majority of instructors emerged in virtual teaching have developed their technological knowledge, within a short time, (TK) in spite of their previous exposure to technology and that online teaching has forced teachers to become more innovative and cooperative in their instruction.

Previous studies, such as the one by Sepulveda-Escobar and Morrison (2020), reported that despite the challenges of virtual teaching, teachers reported that such participations boost their experience positively to a certain level in enhancing teacher's education and students' future job opportunities. Similar results were found in the current study, in which teachers reported that the experience of elearning has enriched their expertise and provided them with opportunities to practice new styles of teaching.

Among the advantages offered by e-learning platforms is the provision of diverse and alternative evaluation methods, and one of the objectives of the current study was to survey the opinions of teachers on these methods. Their impressions were positive, and most of them made use of these methods in the assessment process. This is also in line with the findings of Abduh (2021), who asserted that teachers' perceptions of online assessment methods were positive. Nevertheless, the challenges they encountered while assessing their students online were serious .

The teachers participating in the study added that among the advantages of e-learning are convenience, accessibility, and comfort. The same conclusion was found in Mukhtar et al.'s (2020) study, which demonstrated that the advantages of e-learning included remote learning, comfort, and accessibility, whereas the limitations involved inefficiency and difficulty in maintaining academic integrity.

Finally, some previous studies have indicated that the lack of readiness for an e-learning transformation in some educational systems poses an additional obstacle, as do insufficient capabilities and inefficiencies of teachers in using this modern technology. This is greatly in contrast with the outcomes of the current study, which demonstrated the competence of faculty members in dealing with this shift and the readiness of the educational institution and its systems to adapt to e-learning. 


\section{Conclusion}

This study discusses teachers' opinions about e-learning during the COVID -19 pandemic, specifically faculty members who teach English at Qassim University. The research focused on two main axes: the pros and cons of this teaching style. In general, the professors' impressions were positive about e-learning. Furthermore, they related that one of the most important advantages was protection from the virus. They also added that this stage provided them the opportunity to experiment with new teaching methods, assessments, and expertise development. Moreover, they felt that this stage's focus was limited to the actual task of the profession, i.e., teaching, while relieving them from some minor tasks.

As for the obstacles, the teachers faced less obstacles compared to the students. The study showed that the participants did not struggle using technology and had sufficient skills to navigate the technical educational platforms. However, they pointed out that communication with students was not smooth, and remote teaching did not enable them to identify the extent to which students understood the lessons.

Although educational platforms offer modern, diverse assessment methods, they are not considered a substitute for face-to-face interactions, as direct communication is undoubtedly more efficient and offers fairer student assessments.

Notably, the online teaching channels at Qassim University work efficiently, and the institutions are well equipped. Still, this study presents some recommendations, the most important of which is the continuation of performance development and the adoption of the feedback provided by such studies to fill the gaps and increase in efficiency. It is also suggested that teachers be constantly preprepared, via training and development programs, on the optimal use of technology to ensure readiness for any urgent challenges. Finally, this study recommends the development of follow-up methods for teachers, ensuring that they carry out their 'distance' tasks to the fullest without complacency.

\section{Recommendations}

Considering the results of the study, which were mostly in favor of the traditional mode of teaching, the researcher recommends conducting further studies to perform a comprehensive evaluation of all the aspects involved in the E-learning process. Moreover, the study recommends providing the academic institutions with the equipment, tools, and laboratories needed in the application of their online teaching programs. Furthermore, we suggest the use of supervision and follow-up tactics to ensure that instructors are performing their roles fully, particularly with the absence of supervision measures via virtual education. The study recommends establishing permanent educational platforms for broadcasting lectures; these medium work in the offline mode, as is the case with public education schools. These techniques will help overcome the technical problems of online education. The study recommends holding workshops for teachers to train them on the optimal use of the advanced tools of these technologies and not to limit themselves in using simple tools. The researcher also suggests that universities constantly review and update their electronic learning systems so that they work efficiently in times of emergencies.

In conclusion, the study argues that if instructors use all the possible electronic techniques in their teaching methods, the future of E-learning will be constructed in a motivating and interactive environment. Teaching will be both informative and enjoyable. The implementation of these recommendations might be challenging at the outset, but it will definitely yield fruitful educational outcomes. 


\section{References}

Abduh, M. Y. M. (2021). Full-time online assessment during COVID-19 lockdown: EFL teachers' perceptions. Asian EFL Journal, 28(1.1), 26-46.

Al-Ahdal, A. A. M.H, \& Alqasham, F. H. (2020). Saudi EFL learning and assessment in times of Covid-19: Crisis and beyond. Asian EFL Journal, 27(4.3), 356-383.

Al-Khresheh, M. H. (2021). Reconceptualising the elements of effective English language teaching through the lens of pandemic induced online teaching: An exploratory study of Jordanian EFL teachers' perceptions. Asian EFL Journal, 28(2.3), 61-97.

Alebaikan, R., \& Troudi, S. (2016). Blended learning in Saudi universities: Challenges and perspectives. Research in Learning Technology, 18(1), 49-59. https://doi.org/10.1080/09687761003657614

Almansour, M. I., \& Al-Ahdal, A. A. M. H. (2020). University education in KSA in COVID times: Status, challenges and prospects. International Journal of Innovation, Creativity and, 14(3), 971984.https://www.ijicc.net/images/Vol_14/Iss_3/14359_Almansour_2020_E_R.pdf

Alves, R., Lopes, T., \& Precioso, J. (2021). Teachers' well-being in times of COVID-19 pandemic: Factors that explain professional well-being. International Journal of Educational Research and Innovation, 15, 203-217. https://doi.org/10.46661/ijeri.5120

Astuti, M., \& Solikhah, I. (2021). Teacher perception in teaching English for SMP in Klaten Regency during COVID-19 outbreak. Journal of Transformative Learning, 6(1), 1-13. https://doi.org/10.30957/ijotl-tl.v6i1.645

Atmojo, A. E. P., \& Nugroho, A. (2020). EFL classes must go online! Teaching activities and challenges during COVID-19 pandemic in Indonesia. Register Journal, 13(1), 49-76. https://doi.org/10.18326/rgt.v13i1.49-76

Bailey, D. R., \& Lee, A. R. (2020). Learning from experience in the midst of COVID-19: Benefits, challenges, and strategies in online teaching. Computer-Assisted Language Learning Electronic Journal, 21(2), 178-198.

Fansury, A. H., Januarty, R., \& Syawal, A. W. R. (2020). Digital content for millennial generations: Teaching the English foreign language learner on COVID-19 pandemic. Journal of Southwest Jiaotong University, 55(3). https://doi.org/10.35741/issn.0258-2724.55.3.40

Hazaea, A. N., Bin-Hady, W. R. A., \& Toujani, M. M. (2021). Emergency remote English language teaching in the Arab league countries: Challenges and remedies. CALL-EJ, 22(1), 201-222.

Khatoony, S., \& Nezhadmehr, M. (2020). EFL teachers' challenges in integration of technology for online classrooms during coronavirus (COVID-19) pandemic in Iran. The Asian Journal of English Language and Pedagogy, 8(2). https://doi.org/10.37134/ajelp.vol8.sp.1.2020

Kitishat, A. R., Omar, K. H. A. M., \& Momani, A. K. A. (2020). The COVID-19 crisis and distance learning: E-Teaching of language between reality and challenges. The Asian ESP Journal, 16(5.1), $316-326$.

Kundu, A., \& Bej, T. (2021). COVID-19 response: An analysis of teachers' perception on pedagogical successes and challenges of digital teaching practice during new normal. Education and Information Technologies. https://doi.org/10.1007/s10639-021-10503-5 
Lestiyanawati, R. (2020). The strategies and problems faced by Indonesian teachers in conducting elearning during COVID-19 outbreak. CLLiENT (Journal of Culture, Literature, Linguistics and English Teaching), 2(1), 71-82.

Tamah, S. M., Gozali, I., Triwidayati, K. R., Utami, T. S. D., \& Jemadi, F. (2020). Secondary school language teachers' online learning engagement during the COVID-19 pandemic in Indonesia. Journal of Information Technology Education: Research, 19, 803-832.

Mukhtar, K., Javed, K., Arooj, M., \& Sethi, A. (2020). Advantages, limitations and recommendations for online learning during COVID-19 pandemic era. Pakistan Journal of Medical Sciences, 36, S27-S31 https://doi.org/10.12669/pjms.36.COVID19-S4.2785

Nambiar, D. (2020). The impact of online learning during COVID-19: Students' and teachers' perspective. The International Journal of Indian Psychology, 8(2), 783-793. https://doi.org/10.25215/0802.094

Nashir, M., \& Laili, R. N. (2021). English teachers' perception toward the switch from offline to online teaching during lockdown in the midst of COVID-19 outbreak. Edukatif: Jurnal Ilmu Pendidikan, 3(2), 250-260. https://doi.org/10.31004/edukatif.v3i2.287

Sepulveda-Escobar, P., \& Morrison, A. (2020). Online teaching placement during the COVID-19 pandemic in Chile: Challenges and opportunities. European Journal of Teacher Education, 43(4), 587-607. https://doi.org/10.1080/02619768.2020.1820981

Shamsan, M. A. A., Ali, J. K. M., \& Hezam, T. A. (2021). Online learning amid COVID-19 pandemic: A case study of vocabulary learning strategies. Arab World English Journal, 1(Special Issue on Covid 19 Challenges), 281-294. https://doi.org /10.24093/awej/covid.21

Putri, R. S., Purwanto, A., Pramono, R., Asbari, M., Wijayanti, L. M., \& Hyun, C. C. (2020). Impact of the COVID-19 pandemic on online home learning: An explorative study of primary schools in Indonesia. International Journal of Advanced Science and Technology, 29(5), 4809-4818.

Yi, Y., \& Jang, J. (2020). Envisioning possibilities amid the COVID- 19 pandemic: Implications from English language teaching in South Korea. TESOL Journal, 11(3). https://doi.org/10.1002/tesj.543

\section{AUTHOR BIODATA}

Dr. Yasamiyan Saleh Alolaywi is an Assistant Professor of Applied Linguistics in the Department of English Language and Translation, College of Science and Arts, Methnab, Qassim University, Saudi Arabia. Her research interests include teacher professional development, pragmatics, and translation. Dr. Alolaywi has presented research at national and international conferences. She has also published research in highly ranked journals, including Scopus-indexed journals. In addition, she is a certified and licensed trainer both nationally and internationally. She has held a number of training workshops on areas including translation, research writing, and language teaching. She has been teaching English for more than 17 years and has taught a number of translation and linguistics courses at the B.A. level, including Translation Theories, Interpreting, Introduction to Translation, Introduction to Linguistics, Syntax and Morphology, and Semantics and Pragmatics. Moreover, she has two Certificates of Authority in Arabic Syntax from the Arabic Academy of Syntax. 


\section{Appendix A}

Dear Instructor,

The Survey

You are invited to take part in a survey about teaching online during the COVID-19 pandemic. The main objective of this survey is to investigate your opinion about online teaching and identify the pros and cons of this mode of education. The survey should take a maximum of seven minutes to complete.

Your participation is entirely voluntary, yet it is highly valuable in helping us gain insights into the implications of the current pandemic for learning and teaching processes. Your responses will be both anonymous and confidential. Data obtained from this survey will be used for research purposes only.

Thank you in advance for your cooperation.

The researcher,

Dr. Yasamiyan

1. Gender:

Male

Female

2. How long have you been teaching English?

3. University:

4. Faculty:

5. Degree:

- Post-doctoral

- Doctoral

- Master's

- Bachelor's

- Diploma

- Other (please specify)

6. Position:

- Full Professor

- Associate Professor

- Assistant Professor

- Lecturer

- Teaching Assistant/Demonstrator

- Language Teacher

- Other (please specify)

7. Which educational platform are you currently using?

- Blackboard

- Zoom

- Both

- Other (please specify)

8. If you are using one more than the other, which one do you prefer? Why?

\section{Choose your response to the following:}


1. I frequently experience technical problems while teaching online.

Strongly disagree

Disagree

Neutral

Agree

Strongly agree

2. Online teaching platforms offer innovative methods of teaching.

Strongly disagree

Disagree

Neutral

Agree

Strongly agree

3. Students understand lectures fully while studying online.

Strongly disagree

Disagree

Neutral

Agree

Strongly agree

4. My students struggle with online learning.

Strongly disagree

Disagree

Neutral

Agree

Strongly agree

5. The online learning environment is not an interactive teaching environment.

Strongly disagree

Disagree

Neutral

Agree

Strongly agree

6. Teaching techniques are limited within virtual classrooms.

Strongly disagree

Disagree

Neutral

Agree

Strongly agree

7. Online mediums offer additional tools useful for in-class discussions (e.g., live chats, voice answer).

Strongly disagree

Disagree

Neutral

Agree

Strongly agree

8. Students can interact easily with their instructors through online teaching channels.

Strongly disagree

Disagree

Neutral

Agree

Strongly agree

9. I can easily assess my students and track their progress while teaching online.

Strongly disagree

Disagree

Neutral

Agree

Strongly agree 
10. Online teaching platforms offer innovative methods of assessment.

Strongly disagree

Disagree

Neutral

Agree

Strongly agree

11. I enjoy the experience of teaching online.

Strongly disagree

Disagree

Neutral

Agree

Strongly agree

12. I prefer online teaching to traditional in-class teaching.

Strongly disagree

Disagree

Neutral

Agree

Strongly agree

13. Educational platforms offer multimedia teaching tools that are absent in traditional classrooms (e.g., audio and visual aids).

Strongly disagree

Disagree

Neutral

Agree

Strongly agree

14. I take advantage of online educational platform tools.

Strongly disagree

Disagree

Neutral

Agree

Strongly agree

15. I think that online teaching can easily replace traditional in-class teaching.

Strongly disagree

Disagree

Neutral

Agree

Strongly agree

16. Online studying has no negative effects on students' performance.

Strongly disagree

Disagree

Neutral

Agree

Strongly agree

17. I see no change in students' achievement levels as a result of online learning.

Strongly disagree

Disagree

Neutral

Agree

Strongly agree

18. Teaching online is boring.

Strongly disagree

Disagree

Neutral

Agree

Strongly agree 
19. In your opinion, what are the advantages of online teaching?

Strongly disagree

Disagree

Neutral

Agree

Strongly agree

20. In your opinion, what are the disadvantages of online teaching?

Strongly disagree

Disagree

Neutral

Agree

Strongly agree 